OPEN ACCESS

\title{
Experimental study on the influence of preliminary desiccation on the swelling pressure and hydraulic conductivity of compacted bentonite
}

\author{
LIN ZHI LANG ${ }^{1, *}$, WIEBKE BAILLE ${ }^{1}$, SNEHASIS TRIPATHY $^{2}$ AND \\ TOM SCHANZ ${ }^{1, \dagger}$ \\ 'Department of Civil and Environmental Engineering, Ruhr-Universität Bochum, Bochum, Germany \\ 2 Geoenvironmental Research Centre, School of Engineering, Cardiff University, Cardiff, UK
}

(Received 19 January 2018; revised 3 July 2018; Accepted Manuscript published online: 17 December 2018; Version of Record published online: 1 February 2019; Guest Associate Editor: R. Dohrmann)

\begin{abstract}
In deep geological repositories, compacted bentonites have been proposed for use as barrier materials for isolating nuclear waste. The prevailing thermo-hydro-mechanical boundary conditions in the repositories may affect the swelling capacity and permeability of the compacted bentonites. In this study, the effect of preliminary desiccation on the subsequent hydro-mechanical behaviour (swelling pressure and hydraulic conductivity) of compacted Calcigel bentonite was investigated experimentally at $22^{\circ} \mathrm{C}$ and $80^{\circ} \mathrm{C}$. In the first stage of the test, the compacted specimens were subjected to suction-controlled desiccation at $22^{\circ} \mathrm{C}$ and $80^{\circ} \mathrm{C}$ using the vapour-equilibrium technique. After the water content reached equilibrium at a given suction, the axial, radial and volumetric shrinkage strains were measured. Afterwards, constant-volume swelling-pressure tests were performed on the desiccated specimens (second test stage) by saturating the dried specimens with deionized water at $22^{\circ} \mathrm{C}$ and $80^{\circ} \mathrm{C}$. At the end of the swelling-pressure test, the hydraulic conductivities of four saturated specimens were measured at each temperature. The volumetric shrinkage strain of the compacted bentonite during desiccation is controlled by suction instead of temperature. In addition, the preliminary desiccation increases both the swelling pressure and hydraulic conductivity of compacted bentonite, particularly if compacted bentonite undergoes extreme desiccation at an applied suction of $>700 \mathrm{MPa}$.
\end{abstract}

KEYWORDS: compacted bentonite, desiccation, shrinkage, suction, swelling pressure, permeability.

\footnotetext{
†Deceased 12 October 2017

*E-mail: linzhi.lang@rub.de

This paper was presented during the " 7 th International Conference on Clays in Natural and Engineered Barriers for Radioactive Waste Confinement', September 2017. https://doi.org/10.1180/clm.2018.53

This is an Open Access article, distributed under the terms of the Creative Commons Attribution licence (http:// creativecommons.org/licenses/by/4.0/), which permits unrestricted re-use, distribution, and reproduction in any medium, provided the original work is properly cited.
}

Compacted bentonite is one of the candidate bufferclay materials for the deep geological disposal of highlevel radioactive wastes (HLWs) (e.g. Pusch, 1980b; Bucher \& Müller, 1989; Komine \& Ogata, 1996; Delage et al., 1998; Lloret et al., 2003; Schanz \& Tripathy, 2009; Ye et al., 2009; Yigzaw et al., 2016). Because of its high swelling ability and low permeability, the compacted bentonite buffer is suitable for safely isolating HLWs from the biosphere.

Compacted bentonite blocks, initially unsaturated, are installed in a disposal hole of a disposal tunnel (Fig. 1). In the disposal hole, the compacted bentonite 


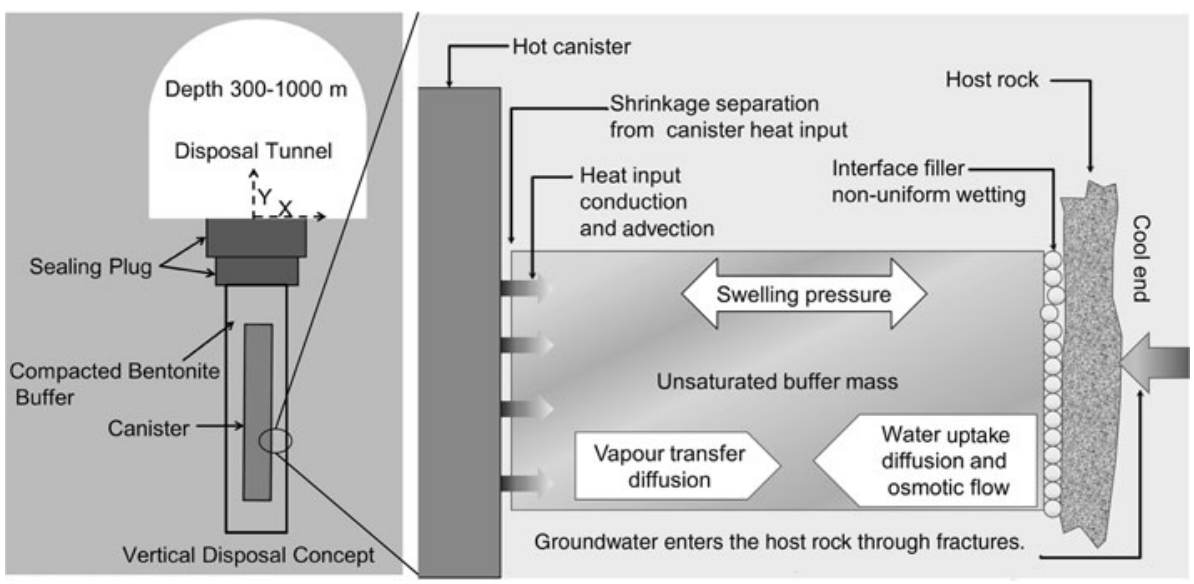

FIG. 1. Schematic view of the deep geological disposal of HLWs (modified after Pusch \& Yong, 2006).

blocks are placed in the gap between the cold host rock and the hot canister containing HLWs. Sealing the disposal hole is generally initiated after installation of all buffer components and canisters (Johannesson et al., 2014). Before sealing the disposal hole, a buffer protection made of a plastic or of rubber is installed in the technical gap between the host rock and buffer blocks. This protection prevents the buffer blocks from adsorbing water from the wet host rock before initiating the backfilling work. Through the duration of protection ( $\sim 3$ months), the bentonite buffer blocks are usually under a thermal gradient.

The hydro-mechanical behaviour of compacted bentonite-based materials under a thermal gradient has been studied using column tests, mock-ups and full-scale tests (e.g. Åkesson et al., 2009; Johannesson et al., 2014; Villar et al., 2016; Tripathy et al., 2017). With increasing distance between the measuring sites and the heater that simulates the hot canister, the water content of the measuring sites increases, whereas the bulk density decreases. Also, under a thermal gradient, water in the unsaturated bentonite-based materials migrates from high temperatures (hot zones) to low temperatures (cold zones). This water migration finally results in dehydration and shrinkage of the bentonite buffer close to the high-temperature zone. Preliminary desiccation due to this thermal gradient may further affect the swelling ability and permeability of the bentonite buffer close to the high-temperature zone.

Previous studies have addressed the influence of preliminary desiccation on the subsequent swelling behaviour and permeability of clays in cyclical wetting-drying experiments (e.g. Osipov et al., 1987; Day, 1994; Al-Homoud et al., 1995; Alonso et al.,
1999; Albrecht \& Benson, 2001; Akcanca \& Aytekin, 2014). However, studies of the influence of preliminary desiccation at elevated temperatures $\left(\right.$ i.e. $80^{\circ} \mathrm{C}$ ) on the subsequent swelling behaviour and permeability of compacted bentonite have not been undertaken. Previous studies using cyclical wetting-drying tests suggest that desiccation will significantly increase the hydraulic conductivity of the compacted clays. Conclusions about this swelling behaviour are not unequivocal, however, because both increases and decreases in the swelling ability of clays have been reported to result from preliminary desiccation.

The objective of this study was to evaluate the effect of preliminary desiccation on the swelling pressure and hydraulic conductivity of a compacted $\mathrm{Ca}, \mathrm{Mg}$-rich bentonite. Specimens with a similar compaction dry density first underwent suction-controlled desiccation at $22^{\circ} \mathrm{C}$ and $80^{\circ} \mathrm{C}$. The change in water content of each specimen was monitored during the desiccation by periodically recording the weight of the specimen. Equilibrium in the water content is generally assumed when the weight of a specimen remains unchanged. Subsequently, constant-volume swelling-pressure tests were performed on the specimens. The specimens dried at $22^{\circ} \mathrm{C}$ and $80^{\circ} \mathrm{C}$ were saturated with deionized water at $22^{\circ} \mathrm{C}$ and $80^{\circ} \mathrm{C}$, respectively. After the swelling pressure reached equilibrium, the hydraulic conductivities of four saturated specimens were measured at the respective temperatures.

\section{MATERIALS}

The material used in this study was Calcigel bentonite, from Bavaria, Germany, purchased from Süd-Chemie 
TABLE 1. Mineralogical composition.

\begin{tabular}{lc}
\hline Mineral & Amount (\%) \\
\hline Smectite/montmorillonite & $60-70$ \\
Quartz & $6-9$ \\
Feldspar & $1-4$ \\
Kaolinite & $1-2$ \\
Mica & $1-6$ \\
Calcite & $2-4$ \\
Dolomite & $1-3$ \\
Others & 3 \\
\hline
\end{tabular}

AG Moosburg, Germany, which has been considered to be one of the potential buffer and backfilling materials in the German multi-barrier concept for disposing of HLWs (Xie et al., 2012). The mineralogical composition and main properties of the bentonite are listed in Table 1 and Table 2, respectively. The mineralogical composition provided by Süd-Chemie AG Moosburg, Germany, was similar to that reported in the literature (Madsen, 1998; Agus, 2005; Schanz \& Tripathy, 2009; Baille, 2014). The total specific surface area, measured by the ethylene glycol monoethyl ether (EGME) method (Cerato \& Lutenegger, 2002), was $436 \mathrm{~m}^{2} / \mathrm{g}$. The total cation exchange capacity was $74 \mathrm{cmol}(+) / \mathrm{kg}$ and the exchangeable cations were $\mathrm{Na}^{+}(2 \mathrm{cmol}(+) / \mathrm{kg}), \mathrm{Ca}^{2+}(27 \mathrm{cmol}$ $(+) / \mathrm{kg})$ and $\mathrm{Mg}^{2+}(19 \mathrm{cmol}(+) / \mathrm{kg})$ (Baille, 2014). The liquid limit, plastic limit and shrinkage limit were 119\%, $45 \%$ and $10 \%$, respectively. The $<2 \mu$ m clay fraction was $54 \%$ and the particle specific gravity was 2.80 .

\section{EXPERIMENTAL METHODS}

\section{Preparation of the compacted specimens}

An adequate amount of water was mixed with the bentonite powder (particle size $<0.1 \mathrm{~mm}$ ) in ambient

TABLE 2. Material properties.

\begin{tabular}{lc}
\hline Property & $\begin{array}{c}\text { Calcigel } \\
\text { bentonite }\end{array}$ \\
\hline Specific gravity & 2.80 \\
Liquid limit (\%) & 119 \\
Plastic limit (\%) & 45 \\
Shrinkage limit (\%) & 10 \\
Total specific surface area $\left(\mathrm{m}^{2} / \mathrm{g}\right)$ & 436 \\
Cation exchange capacity $(\mathrm{cmol}(+) / \mathrm{kg})$ & 74 \\
\hline
\end{tabular}

laboratory conditions and the sample was kept in a sealed bucket for 2 weeks to allow for water content equilibrium. Subsequently, the water content and total suction of the prepared bentonite were measured by drying at $105^{\circ} \mathrm{C}$ and with a chilled-mirror hygrometer (AquaLab-3TE, Meter Group), respectively. The remaining material was used to produce the compacted specimens by statically compacting the bentonite in a stainless-steel sample ring (50.0-50.5 mm inner diameter and $20.0 \mathrm{~mm}$ height) to a target height of $15.2 \mathrm{~mm}$. The initial compaction dry density (named 'dry density after compaction' in Table 3 ) varied slightly from 1.56 to $1.59 \mathrm{mg} / \mathrm{m}^{3}$. For all of the compacted bentonite specimens, the initial water content and total suction values were $20.0 \%$ and $14 \mathrm{MPa}$, respectively.

\section{Suction-controlled desiccation tests at $22^{\circ} \mathrm{C}$ and $80^{\circ} \mathrm{C}$}

The drying tests were carried out using the watervapour technique. A schematic diagram of the drying test setup used is shown in Fig. 2. The drying phase was applied to all of the specimens except specimens 100B-9, 100B-15, 100B-16 and 100B-17, which were used as reference specimens and thus did not undergo preliminary desiccation.

A compacted specimen with a sample ring was placed on a plastic mesh that was fixed in the middle of a desiccator (Fig. 2a). The saturated salt solution at the bottom of a sealed desiccator provided a constant relative humidity $(\mathrm{RH})$ at a given temperature. Various $\mathrm{RH}$ conditions were applied by using various aqueous solutions at the respective controlled temperatures. The saturated solutions used in this study are presented in Table 4. The temperatures during the tests were controlled by placing the desiccator in an oven at 80 $\pm 0.1^{\circ} \mathrm{C}$ or in a constant temperature-controlled room at $22 \pm 0.1^{\circ} \mathrm{C}$. For a given saturated aqueous solution at temperatures of $22^{\circ} \mathrm{C}$ and $80^{\circ} \mathrm{C}$, the corresponding suction values were determined separately using the device shown in Fig. 2b. The device consists of a tightly closed container with a provision to insert two sensors for RH and temperature measurements. The sensors used in the present study were VAISALA HMP337, which consists of a humidity sensor based on the correlation of humidity to dielectric characteristics (capacitive-type RH sensor), and a thermocouple for temperature measurement. The RHs measured at the two temperatures of $22^{\circ} \mathrm{C}$ and $80^{\circ} \mathrm{C}$ were in agreement with those that have been reported in the literature (Greenspan, 1977; Delage et al., 1998; Tang \& Cui, 2005). According to the RHs and temperatures 
TABLE 3. Overview of the testing programme with applied temperatures and suctions, dry densities at various test stages, and swelling pressures and hydraulic conductivities in the saturated state.

\begin{tabular}{|c|c|c|c|c|c|c|c|c|}
\hline \multirow{2}{*}{ Sample no. } & \multirow[t]{2}{*}{$\begin{array}{c}\text { After } \\
\text { compaction }\end{array}$} & \multirow{2}{*}{\multicolumn{2}{|c|}{$\begin{array}{cc}\text { After } & \text { After } \\
\text { desiccation } & \text { hydration } \\
\text { Dry density, } \rho_{\mathrm{d}}\left(\mathrm{Mg} / \mathrm{m}^{3}\right)\end{array}$}} & \multirow{2}{*}{$\begin{array}{c}\text { After } \\
\text { dismantling }\end{array}$} & \multirow{2}{*}{$\begin{array}{c}\text { Applied } \\
\text { suction during } \\
\text { desiccation } \\
\psi(\mathrm{MPa})\end{array}$} & \multirow{2}{*}{$\begin{array}{c}\text { Applied } \\
\text { temperature } \\
T\left({ }^{\circ} \mathrm{C}\right)\end{array}$} & \multicolumn{2}{|c|}{$\begin{array}{l}\text { Hydration phase: measured } \\
\text { swelling, pressure }\left(P_{\mathrm{s}}\right) \text { and } \\
\text { hydraulic conductivity }(k)\end{array}$} \\
\hline & & & & & & & $P_{\mathrm{s}}(\mathrm{MPa})$ & $k(\mathrm{~m} / \mathrm{s})$ \\
\hline 100B-1 & 1.588 & 1.740 & 1.563 & 1.474 & 1000 & $105^{a} / 22^{b}$ & 3.48 & - \\
\hline 100B-2 & 1.582 & 1.744 & 1.575 & 1.546 & 700 & $80 / 80$ & 2.60 & $2.0 \times 10^{-11}$ \\
\hline 100B-3 & 1.581 & 1.738 & 1.574 & 1.548 & 367 & $80 / 80$ & 2.53 & - \\
\hline 100B-4 & 1.586 & 1.727 & 1.582 & 1.550 & 219 & $80 / 80$ & 2.66 & - \\
\hline 100B-5 & 1.585 & 1.698 & 1.588 & 1.558 & 184 & $80 / 80$ & 2.90 & - \\
\hline 100B-6 & 1.590 & 1.661 & 1.589 & - & 104 & $80 /-$ & - & - \\
\hline 100B-7 & 1.583 & 1.660 & 1.576 & 1.564 & 44 & $80 / 80$ & 2.50 & $1.2 \times 10^{-11}$ \\
\hline 100B-8 & 1.588 & 1.615 & - & - & 39 & $80 /-$ & - & - \\
\hline $100 \mathrm{~B}-9^{c}$ & 1.576 & - & 1.576 & 1.555 & - & $-/ 80$ & 2.22 & $4.6 \times 10^{-12}$ \\
\hline 100B-10 & 1.585 & 1.531 & - & - & 8 & $80 /-$ & - & - \\
\hline 100B-11 & 1.567 & 1.732 & 1.572 & 1.510 & 346 & $22 / 22$ & 2.67 & - \\
\hline 100B-12 & 1.580 & 1.683 & 1.585 & 1.508 & 154 & $22 / 22$ & 2.90 & - \\
\hline 100B-13 & 1.580 & 1.666 & 1.572 & 1.504 & 83 & $22 / 22$ & 2.55 & - \\
\hline 100B-14 & 1.580 & 1.614 & 1.574 & - & 39 & $22 /-$ & - & - \\
\hline $100 \mathrm{~B}-15^{c}$ & 1.562 & - & 1.562 & 1.483 & - & $-/ 22$ & 2.35 & - \\
\hline $100 \mathrm{~B}-16^{c}$ & 1.586 & - & 1.586 & - & - & $-/ 22$ & 2.88 & - \\
\hline $100 \mathrm{~B}-17^{c}$ & 1.573 & - & 1.573 & 1.506 & - & $-/ 22$ & 2.52 & $7.7 \times 10^{-13}$ \\
\hline
\end{tabular}

${ }^{a}$ Value refers to the applied temperature during the desiccation phase.

${ }^{b}$ Value refers to the temperature during the hydration phase.

${ }^{c}$ Reference sample without undergoing preliminary desiccation phase. 


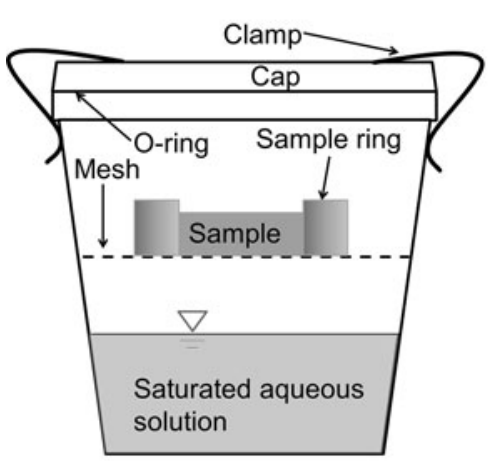

(a)

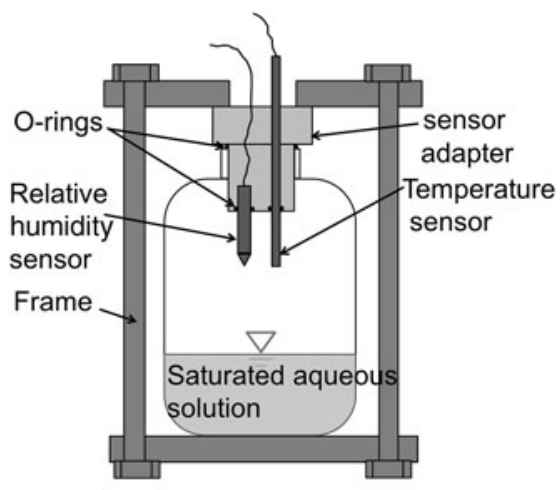

(b)

FIG. 2. Schematic diagram of: (a) suction-control device; and (b) device for measuring the suction of saturated aqueous solutions.

measured in this study, the applied total suction $(\psi)$ was calculated using equation 1 (Fredlund et al., 2012):

$$
\psi=-\frac{\mathrm{R} T_{K}}{v_{w 0} \omega_{v}} \ln (R H)
$$

where $\mathrm{R}$ is the universal (molar) gas constant (i.e. $8.31432 \mathrm{~J} /[\mathrm{mol} \mathrm{K}]) ; T_{K}$ is the absolute temperature $273.15+T(\mathrm{~K}), \quad T=$ temperature $\left({ }^{\circ} \mathrm{C}\right) ; v_{\omega 0}$ is the specific volume of water or the inverse of the density of water $\left(\mathrm{m}^{3} / \mathrm{kg}\right) ; \omega_{v}$ is the molecular mass of water vapour (i.e. $18.016 \mathrm{~kg} / \mathrm{kmol}$ ); and $R H$ is the measured relative humidity.

The applied suction values during the drying tests for each specimen are listed in Table 3. In addition, it was assumed that the dry state of a specimen after oven drying at a temperature of $105^{\circ} \mathrm{C}$ corresponds to a suction of $1000 \mathrm{MPa}$ (Fredlund et al., 2012). An oven with a temperature of $80^{\circ} \mathrm{C}$ provided suction of $700 \mathrm{MPa}$ (Table 3), which was determined by RH and temperature measurements in the oven atmosphere. During the drying tests, the mass change of each specimen was determined periodically by removing it from the container and weighing it on a balance with a readability of $0.001 \mathrm{~g}$. Once the mass of the specimens reached equilibrium (variation of specimen mass $<0.001 \mathrm{~g}$ ), the diameter and height of each specimen were measured using a calliper, and the dry density values were also calculated (referred to here as 'dry density after desiccation' in Table 3).

\section{Swelling-pressure and hydraulic-conductivity tests}

After the drying tests were terminated, all of the dried specimens except specimens 100B-6, 100B-8, 100B-10 and 100B-14 (Table 3) were transferred into an isochoric swelling-pressure device as shown in Fig. 3 (Romero, 1999; Schanz \& Tripathy, 2009). Prior to use, the deformation of the isochoric swellingpressure device and the load-cell measurement were calibrated with respect to the non-isothermal test conditions. Details of the calibration were given by Arifin (2008). The swelling-pressure tests were performed as one-step tests by supplying deionized water at the respective temperatures used in the preliminary desiccation phase.

Due to the preliminary desiccation, all of the specimens except 100B-10 and the reference specimens experienced volumetric shrinkage, leading to increases in dry density (Table 3). Consequently, these

TABLE 4. Measured equilibrium suction, $\psi(\mathrm{MPa})$, of the saturated solutions used at $22^{\circ} \mathrm{C}$ and $80^{\circ} \mathrm{C}$.

\begin{tabular}{lcccccccc}
\hline$T\left({ }^{\circ} \mathrm{C}\right)$ & $\mathrm{NaOH}$ & $\mathrm{LiCl}$ & $\mathrm{MgCl}_{2}$ & $\mathrm{Mg}\left(\mathrm{NO}_{3}\right)_{2}$ & $\mathrm{NaNO}_{2}$ & $\mathrm{NaCl}$ & $\mathrm{KCl}$ & $\mathrm{K}_{2} \mathrm{SO}_{4}$ \\
\hline 22 & 346 & 282 & 184 & 83 & 58 & 39 & 10 & 2 \\
80 & - & 367 & 219 & 184 & 104 & 44 & 39 & 8 \\
\hline
\end{tabular}




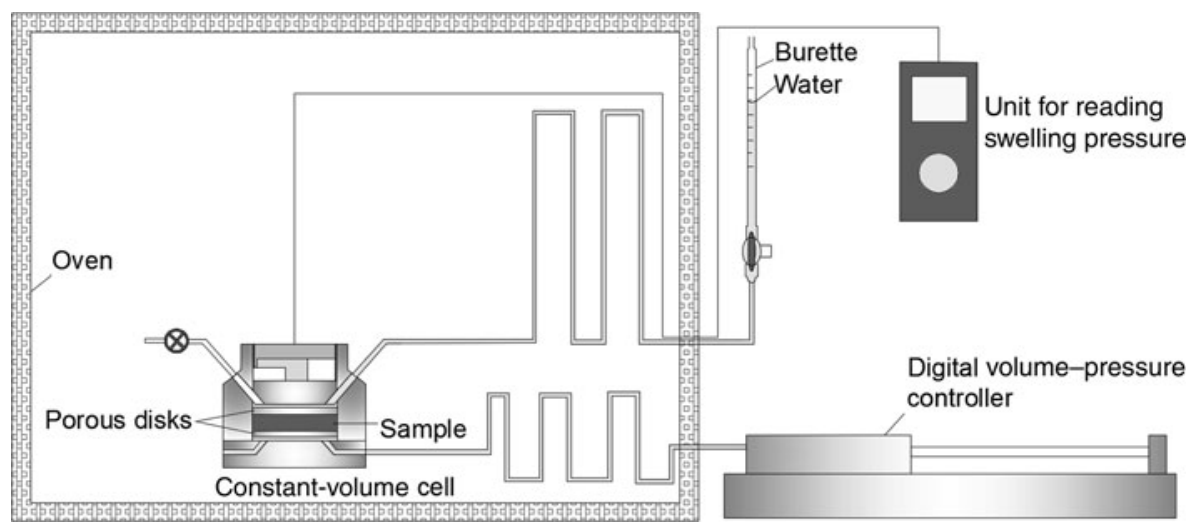

FIG. 3. Experimental setup for the swelling-pressure and hydraulic-conductivity tests.

specimens had diameters of $<50 \mathrm{~mm}$ (inner diameter of the sample ring) and heights of $<15.2 \mathrm{~mm}$. The height of $15.2 \mathrm{~mm}$ corresponded to the net space height of the sample ring when the isochoric swellingpressure device was assembled. The net space height of the sample ring was $15.2 \mathrm{~mm}$ because the height of the piston and upper porous disk was $4.8 \mathrm{~mm}$. Because small initial radial and vertical gaps existed at the start of the hydration phase, the initial phase of hydration corresponded to the free-swelling condition. Hydration of the desiccated specimens under constant-volume conditions occurred until the initial radial and vertical gaps were filled with swollen bentonite particles.

The hydraulic conductivities of four saturated specimens (i.e. 100B-17, 100B-2, 100B-7 and 100B9) were measured at the end of the hydration phase at the respective temperatures. Specimen 100B-17 was tested at $22^{\circ} \mathrm{C}$ and specimens 100B-2, 100B-7 and $100 \mathrm{~B}-9$ were tested at $80^{\circ} \mathrm{C}$. The experimental setup is shown in Fig. 3. A constant water-pressure head of $24 \mathrm{kPa}$ was applied by a volume-pressure controller at the bottom of specimen and the outflow at top of the specimen was measured using a burette. When the flows reached steady state, the saturated coefficient of hydraulic conductivity was calculated according to Darcy's law (Yong \& Warkentin, 1975). The duration of each hydraulic conductivity test was $\sim 45$ days.

At the end of the hydration test, the swellingpressure device was dismantled and the final dry densities of most of the specimens were determined by measuring their height and diameter. The height and diameter measurements show that the preliminary volumetric shrinkage was fully recovered in the desiccated specimens. The final dry densities were $0.8-5.7 \%$ smaller than the dry densities after hydration
(Table 3). This is attributed to the slight deformation of the swelling-pressure device during the swellingpressure test and the expansion of the specimen after releasing the swelling pressure. Because the times taken to dismantle the swelling pressure device and the subsequent measuring of specimen dimensions were not the same for each test, any errors due to these factors cannot be quantified. Therefore, the dry density after saturation was used as the relevant dry density to which the respective measured swelling pressure and hydraulic conductivity referred. The dry density after saturation was determined according to the water content and mass of a specimen before hydration and its volume after saturation under constant-volume conditions. The volume of a saturated specimen was determined based on the diameter of the sample ring $(50.0-50.5 \mathrm{~mm})$ and the net space height of the sample ring $(15.2 \mathrm{~mm})$.

\section{RESULTS AND DISCUSSION}

\section{Relationships between preliminary desiccation, equilibrium water content and suction-water content}

The evolution of water content with time at various applied suctions is presented in Fig. 4a for the drying tests at $22^{\circ} \mathrm{C}$ and in Fig. $4 \mathrm{~b}$ for the drying tests at $80^{\circ} \mathrm{C}$. The equilibrium water contents of all of the specimens except for 100B-10 were less than the initial water content of $20 \%$, as the applied suctions were greater than the initial suction of $14 \mathrm{MPa}$. The equilibrium water content (i.e. 20.7\%) at an applied suction of $8 \mathrm{MPa}$ of specimen 100B-10 was slightly greater than the initial water content. This implies that the suction 
(a)

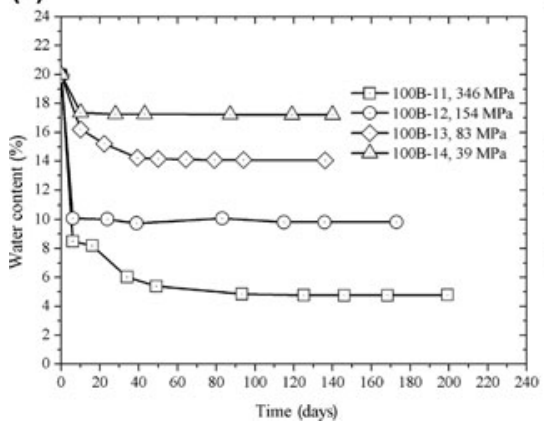

(b)

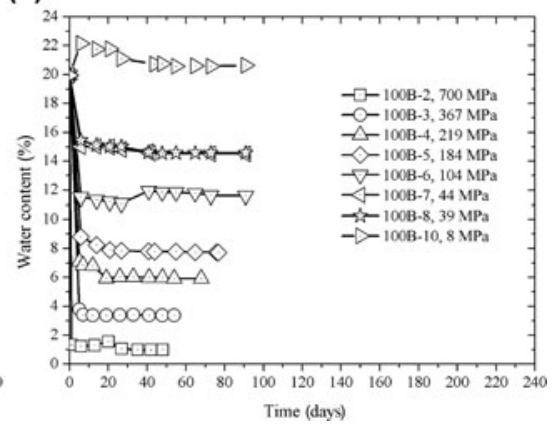

FIG. 4. Evolution of the water content of compacted bentonite with elapsed time during suction-controlled desiccation at (a) $22^{\circ} \mathrm{C}$ and (b) $80^{\circ} \mathrm{C}$ (sample numbers and applied suctions are given in the key).

corresponding to the water content of $20 \%$ at $80^{\circ} \mathrm{C}$ was $>8 \mathrm{MPa}$ but $<14 \mathrm{MPa}$, because the suction of compacted bentonite at a given water content decreased with increasing temperature (Villar et al., 2010).

A comparison of the suction-water content relationships at $22^{\circ} \mathrm{C}$ and $80^{\circ} \mathrm{C}$ is shown in Fig. 5. For a given applied suction, the water content was slightly smaller for the specimens subjected to $80^{\circ} \mathrm{C}$ than for the specimens subjected to $22^{\circ} \mathrm{C}$. In addition, for a given water content, the bentonite suction was smaller at the higher temperature. This implies that, once a thermal gradient is applied to the bentonite buffer with homogeneous initial water content, the suction of the buffer zone close to the heating source decreases, and thus a hydraulic gradient arises. This hydraulic gradient due to the thermal gradient in turn induces water movement from the low-suction region to the high-suction region of the buffer zone.

\section{Preliminary desiccation: shrinkage strains}

The measured axial, radial and volumetric strains against the applied suction for both temperatures are presented in Fig. 6a,b,c, respectively. From the initial state corresponding to $14 \mathrm{MPa}$ suction and zero strain, the axial, radial and volumetric strains increased linearly with increasing suction up to $\sim 400 \mathrm{MPa}$ for both temperatures. Beyond the suction range of $400 \mathrm{MPa}$, a further suction increase did not induce further strain. The suction of $400 \mathrm{MPa}$ corresponds to RHs of $5.2 \%$ at $22^{\circ} \mathrm{C}$ and of $8.5 \%$ at $80^{\circ} \mathrm{C}$. In these conditions, montmorillonites dominated by divalent exchangeable cations (e.g. $\mathrm{Ca}, \mathrm{Mg}$ ) experience transition from mono-hydrated- to dehydrated-layer water states (Mooney et al., 1952; Ferrage et al., 2007; Morodome \& Kawamura, 2009). The removal of single-hydrated layer water probably does not affect macroscopic volume deformation. Consequently, the volumetric shrinkage strain is almost constant for suctions $>400 \mathrm{MPa}$.

Moreover, the axial strain at a given suction was greater at $22^{\circ} \mathrm{C}$ than at $80^{\circ} \mathrm{C}$ (Fig. 6a), whereas the radial strain at a given suction followed the opposite trend (Fig. 6b). Consequently, the effect of temperature on the volumetric strain (Fig. 6c) was minor. The volumetric shrinkage strain of compacted bentonite during desiccation is controlled by suction or hydraulic gradients rather than by applied temperature or thermal gradients (Fig. 6).

\section{Hydration phase: swelling pressure}

The evolution of swelling pressure with elapsed time is presented in Fig. $7 \mathrm{a}$ for the tests at $22^{\circ} \mathrm{C}$ and in Fig. $7 \mathrm{~b}$ for the tests at $80^{\circ} \mathrm{C}$. The equilibrium swelling pressure was established more rapidly at the hydration temperature of $80^{\circ} \mathrm{C}$. The swelling-pressure equilibrium time for the specimens tested at $22^{\circ} \mathrm{C}$ was $\sim 300 \mathrm{~h}$, whereas the swelling-pressure equilibrium time for specimens hydrated at $80^{\circ} \mathrm{C}$ was $\sim 100 \mathrm{~h}$. In addition, for a given temperature, dry density and water content before hydration had almost no influence on the swelling-pressure equilibrium time, but did affect the magnitude of the equilibrium swelling pressure.

Figure 8 presents the equilibrium swelling pressure as a function of the dry density of the saturated specimens. The data in the literature (Schanz \& Tripathy, 2009; Baille et al., 2010) were obtained from constant-volume swelling-pressure tests performed at $20^{\circ} \mathrm{C}$ on compacted Calcigel bentonite with mineralogical composition and material 


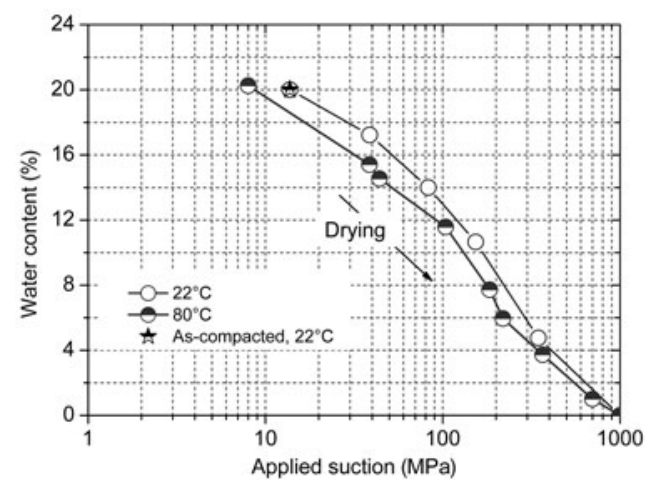

FIG. 5. Applied suction vs. water content of compacted bentonite at $22^{\circ} \mathrm{C}$ and $80^{\circ} \mathrm{C}$.

properties similar to the bentonite used in this study. The swelling pressures in this study were in reasonable agreement with the data from the literature (Fig. 8). In addition, temperature did not affect the swelling pressure-dry density relationship. For a given dry density, the swelling pressures at $80^{\circ} \mathrm{C}$ were slightly lower than those measured at $22^{\circ} \mathrm{C}$ (Fig. 9).

The effect of water content before hydration on swelling pressure for a given dry density and temperature is presented in Fig. 9. The swelling pressure increased with decreasing water content before hydration for a given temperature and dry density. This indicates that the desiccated specimens exhibited greater swelling pressure than the reference specimens (100B-9, 100B-15, 100B-16 and 100B-17), as the latter did not undergo preliminary desiccation and had the highest water content. Moreover, the difference in swelling pressure between the desiccated and reference specimens depended on their difference in water content or the applied suction during the preliminary desiccation. The swelling pressure of specimen 100B-1 dried at an applied suction of $1000 \mathrm{MPa}$ increased by $46 \%$ compared to reference specimen 100B-15. The swelling pressure of specimen 100B-2 dried at an applied suction of $700 \mathrm{MPa}$ increased by $18 \%$ compared with reference specimen 100B-9. The swelling pressures of specimens 100B-11 and 100B-12 dried at applied suctions of 346 and $154 \mathrm{MPa}$, respectively, increased only by $7 \%$ and $1 \%$, respectively. Thus, preliminary desiccation increases the swelling pressure of compacted bentonite (Fig. 9). Furthermore, the increase in the swelling pressure is significant for the compacted bentonite (i.e. specimens 100B-1 and 100B-2) which underwent extreme desiccation at an applied suction of $>700 \mathrm{MPa}$. (a)
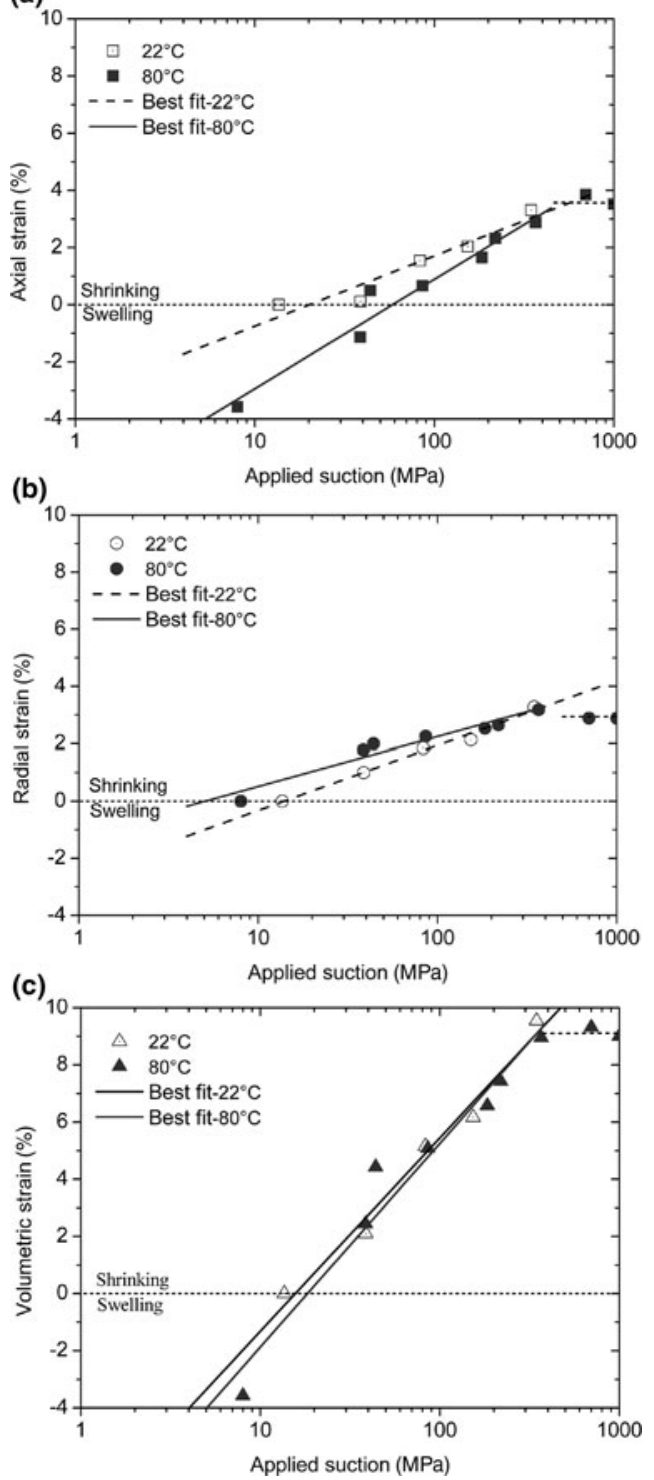

FIG. 6. Applied suction vs. (a) axial, (b) radial and (c) volumetric strains of compacted bentonite at $22^{\circ} \mathrm{C}$ and $80^{\circ} \mathrm{C}$.

The increase in swelling pressure due to preliminary desiccation may be relevant to the influence of desiccation on the fabric of bentonite. Preliminary desiccation, particularly extreme desiccation at an applied suction of $>700 \mathrm{MPa}$, may destroy the dispersed aggregates, resulting in substantial swelling during the subsequent hydration phase. Dryingwetting cycles might significantly increase the 
(a)

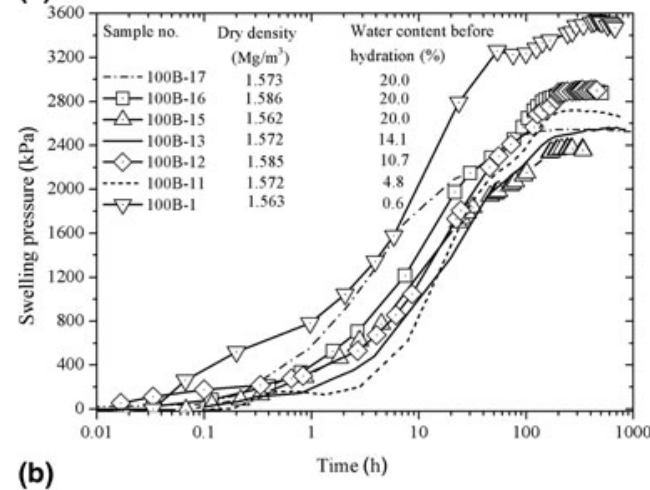

(b)

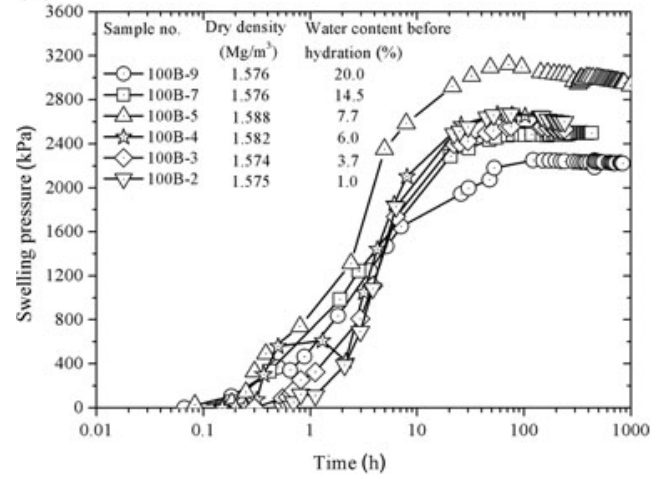

FIG. 7. Evolution of the swelling pressure of compacted bentonite with elapsed time in the case of saturating at (a) $22^{\circ} \mathrm{C}$ and (b) $80^{\circ} \mathrm{C}$.

swelling of clays and destroy the dispersed clay structure (Osipov et al., 1987; Day, 1994). The destruction of large aggregates and the disorientation of structural elements of the clays increased swelling significantly. A decrease in initial water content or an increase in initial suction might lead to greater swelling pressures for a given dry density, and this is related to the effect of initial water content or suction on the fabric of the expansive clays (Gens \& Alonso, 1992; Baille et al., 2010).

\section{Hydraulic conductivity}

Figure 10 shows the measured hydraulic conductivities of saturated specimens 100B-2, 100B-7, 100B-9 and 100B-17. Specimens 100B-17 and 100B-9 were the reference samples and thus did not undergo preliminary desiccation and were hydrated at $22^{\circ} \mathrm{C}$ and $80^{\circ} \mathrm{C}$, respectively. The data from Khan (2012) were obtained from a constant-volume permeability test performed at $20^{\circ} \mathrm{C}$ on a compacted Calcigel

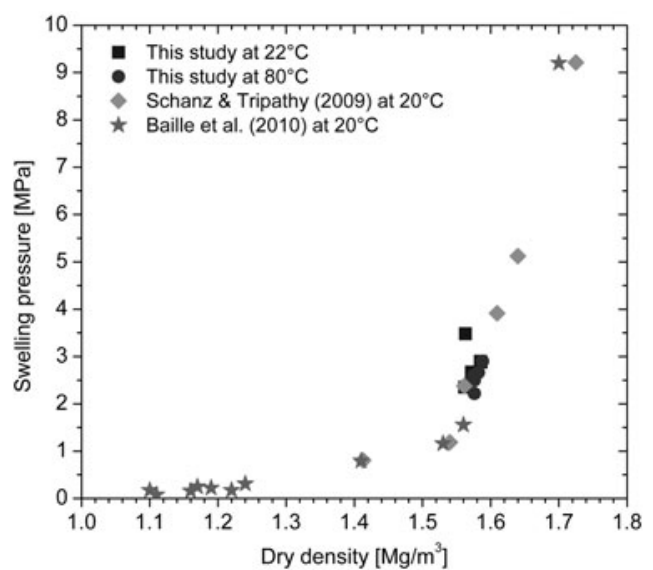

FIG. 8. Dependence of the swelling pressure of compacted bentonite on dry density after hydration.

bentonite specimen with initial compaction conditions similar to those for specimen 100B-17. The magnitudes of their hydraulic conductivities were similar $\left(1.2 \times 10^{-13} \mathrm{~m} / \mathrm{s}\right.$ for the specimen in Khan, 2012, and $7.7 \times 10^{-13} \mathrm{~m} / \mathrm{s}$ for specimen 100B-17). However, the hydraulic conductivity of specimen 100B-17 was significantly lower than that of specimen 100B-9 $\left(4.6 \times 10^{-12} \mathrm{~m} / \mathrm{s}\right)$, indicating that hydraulic conductivity increases with temperature, given that the two reference specimens had similar dry densities and the same water contents before hydration. This result is consistent with earlier findings that the saturated hydraulic conductivity of compacted bentonites increased with increasing temperature (e.g. Pusch, 1980a; Villar et al., 2010; Ye et al., 2013).

At $80^{\circ} \mathrm{C}$ and a dry density of $1.575 \mathrm{Mg} / \mathrm{m}^{3}$, the hydraulic conductivity increased with decreasing water content before hydration (Fig. 10). Reference specimen 100B-9 had the highest water content (i.e. 20\%), but exhibited the lowest hydraulic conductivity $(4.6 \times$ $10^{-12} \mathrm{~m} / \mathrm{s}$ ) compared with specimens 100B-7 and 100B-2. Specimen 100B-17 dried at an applied suction of $44 \mathrm{MPa}$ had a water content of $14.5 \%$ and showed a hydraulic conductivity of $1.2 \times 10^{-11} \mathrm{~m} / \mathrm{s}$. Specimen 100B-2 dried at an applied suction of $700 \mathrm{MPa}$ had the lowest water content (i.e. 1\%), but exhibited the highest hydraulic conductivity $\left(2.0 \times 10^{-11} \mathrm{~m} / \mathrm{s}\right)$. Compared to the hydraulic conductivity of reference specimen 100B-9, the hydraulic conductivities of specimens 100B-7 and 100B-2 increased by $156 \%$ and $334 \%$, respectively. These results indicate that preliminary desiccation increases the hydraulic conductivity of compacted bentonite. Moreover, a 


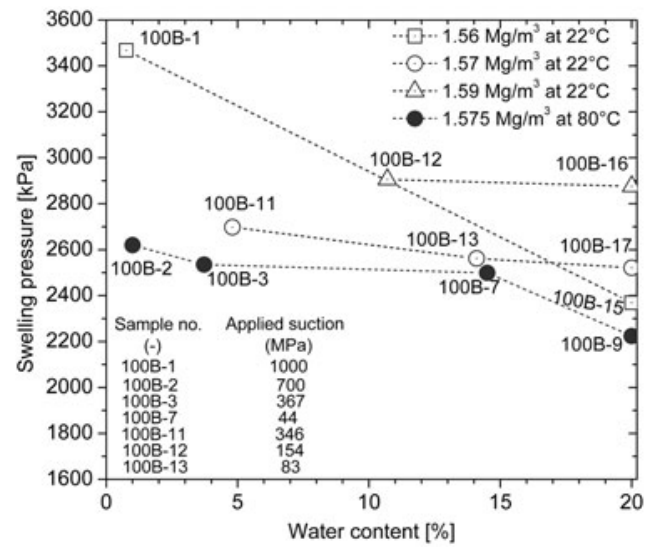

FIG. 9. Dependence of the swelling pressure of compacted bentonite on the water content before hydration for a given temperature and dry density.

considerable increase of the hydraulic conductivity occurs if the compacted bentonite (i.e. specimen 100B-2) undergoes extreme desiccation at an applied suction of $>700 \mathrm{MPa}$.

The increase in hydraulic conductivity due to preliminary desiccation may be a result of the fact that the inhomogeneity induced by shrinkage and subsequent temporary unconfined swelling may induce weaker zones with reduced dry densities and slightly higher permeabilities. The volumetric shrinkage due to preliminary desiccation leads to reduced specimen dimensions. Therefore, the initial stage of hydration corresponded to free-swelling conditions

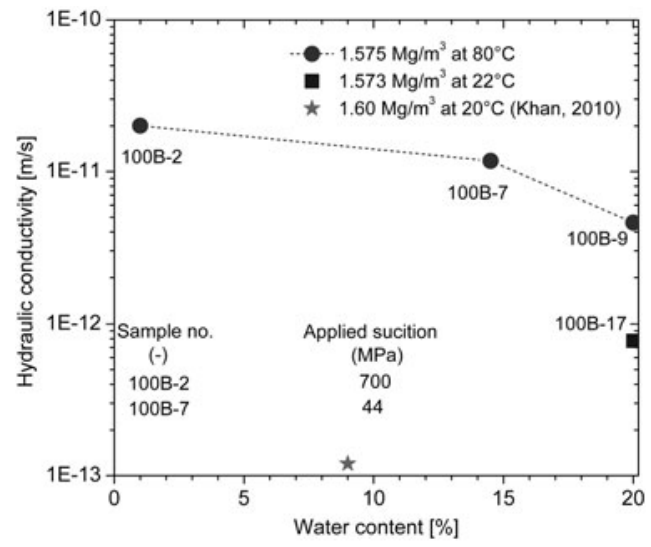

FIG. 10. Dependence of the hydraulic conductivity of compacted bentonite on the water content before hydration for a given temperature and dry density. (without volume constraint). Hydration of the desiccated specimens under constant-volume condition occurred until the initial radial and vertical gaps were filled with swollen bentonite particles. The initial unconfined swelling results in the redistribution of bentonite particles into the former radial and axial gaps, thus leading to a change in the local dry densities of the specimens. The zone of the former gap may have a reduced dry density as compared to the inner core of the specimen and so might provide a preferential flow pathway. Consequently, the desiccated specimens exhibited greater permeability compared with reference samples without preliminary desiccation. A previous study of the effect of initial technical voids on the hydraulic conductivities of compacted bentonite-based materials indicates that, at the same bentonite dry density or void ratio, the specimens with a larger technical void space showed greater hydraulic conductivity (Wang et al., 2013).

\section{SUMMARY AND CONCLUSIONS}

The influence of preliminary desiccation on the subsequent hydro-mechanical behaviour (swelling pressure and hydraulic conductivity) of compacted bentonite was examined experimentally at $22^{\circ} \mathrm{C}$ and $80^{\circ} \mathrm{C}$. For a given level of suction, the equilibrium water content at $22^{\circ} \mathrm{C}$ is slightly greater than that at $80^{\circ} \mathrm{C}$. Moreover, suction rather than temperature dominates the volume shrinkage strain during desiccation. Both the swelling-pressure equilibrium time and equilibrium swelling pressure decrease slightly with increasing temperature, whereas the hydraulic conductivity significantly increases with increasing temperature. In addition, preliminary desiccation increases both the swelling pressure and hydraulic conductivity of compacted bentonite. The increases in the swelling pressure and hydraulic conductivity are significant only if the compacted bentonite undergoes extreme desiccation at an applied suction of $>700 \mathrm{MPa}$.

The present study advances the understanding of the influence of preliminary desiccation on the swelling pressure and hydraulic conductivity of compacted bentonite. The conclusions drawn may provide useful information on designing and constructing for deep geological disposal of HLWs. However, the conclusions in this study are based on the results of Calcigel bentonite specimens with dry densities of 1.56$1.59 \mathrm{mg} / \mathrm{m}^{3}$. Enlargement of the experimental programme to a wide range of initial compaction dry densities and other bentonites would be useful for further assessment of the present conclusions. 


\section{ACKNOWLEDGEMENTS}

The financial support provided by the Deutsche Forschungsgemeinschaft (DFG) through research grant no. SCHA 675/16-1 is gratefully acknowledged. The first author is also grateful to the Chinese Scholarship Council and Ruhr University Research School PLUS (Germany's Excellence Initiative [DFG GSC 98/3]) for their financial assistance.

\section{REFERENCES}

Agus S.S. (2005) An Experimental Study on HydroMechanical Characteristics of Compacted BentoniteSand Mixtures. PhD thesis. Bauhaus-University, Weimar, Germany.

Akcanca F. \& Aytekin M. (2014) Impact of wettingdrying cycles on the hydraulic conductivity of liners made of lime-stabilized sand-bentonite mixtures for sanitary landfills. Environmental Earth Sciences, 72, $59-66$.

Åkesson M., Jacinto A.C., Gatabin C., Sanchez M. \& Ledesma A. (2009) Bentonite THM behaviour at high temperatures: experimental and numerical analysis. Géotechnique, 59, 307-318.

Albrecht B.A. \& Benson C.H. (2001) Effect of desiccation on compacted natural clays. Journal of Geotechnical and Geoenvironmental Engineering, 127, 67-75.

Al-Homoud A.S., Basma A.A., Malkawi A.I.H. \& Bashabsheh M.A.A. (1995) Cyclic swelling behavior of clays. Journal of Geotechnical Engineering, 121, $562-565$.

Alonso E.E., Vaunat J. \& Gens A. (1999) Modelling the mechanical behaviour of expansive clays. Engineering Geology, 54, 173-183.

Arifin Y.F. (2008) Thermo-Hydro-Mechanical Behavior of Compacted Bentonite-Sand Mixtures: An Experimental Study. PhD thesis. Bauhaus-University, Weimar, Germany.

Baille W. (2014) Hydro-Mechanical Behaviour of Clays Significance of Mineralogy. $\mathrm{PhD}$ thesis. RuhrUniversität Bochum, Bochum, Germany.

Baille W., Tripathy S. \& Schanz T. (2010) Swelling pressures and one-dimensional compressibility behaviour of bentonite at large pressures. Applied Clay Science, 48, 324-333.

Bucher F. \& Müller V.M. (1989) Bentonite as a containment barrier for the disposal of highly radioactive wastes. Applied Clay Science, 4, 157-177.

Cerato A. \& Lutenegger A. (2002) Determination of surface area of fine-grained soils by the ethylene glycol monoethyl ether (EGME) method. Geotechnical Testing Journal, 25, 315-321.

Day R.W. (1994) Swell-shrink behavior of compacted clay. Journal of Geotechnical Engineering, 120, 618-623.
Delage P., Howat M.D. \& Cui Y.J. (1998) The relationship between suction and swelling properties in a heavily compacted unsaturated clay. Engineering Geology, 50, $31-48$.

Ferrage E., Kirk C.A., Cressey G. \& Cuadros J. (2007) Dehydration of Ca-montmorillonite at the crystal scale. Part I: structure evolution. American Mineralogist, 92, 994-1006.

Fredlund D.G., Rahardjo H. \& Fredlund M.D. (2012) Unsaturated Soil Mechanics in Engineering Practice. John Wiley \& Sons, Inc., Hoboken, NJ, USA.

Gens A. \& Alonso E.E. (1992) A framework for the behaviour of unsaturated expansive clays. Canadian Geotechnical Journal, 29, 1013-1032.

Greenspan L. (1977) Humidity fixed points of binary saturated aqueous solutions. Journal of Research of the National Bureau of Standards, 81, 89-96.

Johannesson L.-E., Kristensson O., Akesson M., Eriksson P. \& Hedin M. (2014) Tests and Simulations of THM Processes Relevant for the Buffer Installation. SKB, Stockholm, Sweden.

Khan M.I. (2012) Hydraulic Conductivity of Moderate and Highly Dense Expansive Clays. PhD thesis. RuhrUniversität Bochum, Bochum, Germany.

Komine H. \& Ogata N. (1996) Prediction for swelling characteristics of compacted bentonite. Canadian Geotechnical Journal, 33, 11-22.

Lloret A., Villar M.V., Sánchez M., Gens A., Pintado X. \& Alonso E. (2003) Mechanical behaviour of heavily compacted bentonite under high suction changes. Géotechnique, 53, 27-40.

Madsen F.T. (1998) Clay mineralogical investigations related to nuclear waste disposal. Clay Minerals, 33, 109-129.

Mooney R.W., Keenan A.G. \& Wood L.A. (1952) Adsorption of water vapor by montmorillonite. II. Effect of exchangeable ions and lattice swelling as measured by X-ray diffraction. Journal of the American Chemical Society, 74, 1371-1374.

Morodome S. \& Kawamura K. (2009) Swelling behavior of Na- and Ca-montmorillonite up to $150^{\circ} \mathrm{C}$ by in situ X-ray diffraction experiments. Clays and Clay Minerals, 57, 150-160.

Osipov V.I., Bik N.N. \& Rumjantseva N.A. (1987) Cyclic swelling of clays. Applied Clay Science, 2, 363-374.

Pusch R. (1980a) Permeability of Highly Compacted Bentonite. SKB, Stockholm, Sweden.

Pusch R. (1980b) Swelling Pressure of Highly Compacted Bentonite. SKB, Stockholm, Sweden.

Pusch R. \& Yong R.N. (2006) Microstructure of Smectite Clays and Engineering Performance. Taylor \& Francis, London, UK, and New York, NY, USA.

Romero E. (1999) Characterisation and Thermo-HydroMechanical Behaviour of Unsaturated Boom Clay: An Experimental Study. $\mathrm{PhD}$ thesis. Universitat Politècnica de Catalunya, Barcelona, Spain. 
Schanz T. \& Tripathy S. (2009) Swelling pressure of a divalent-rich bentonite: diffuse double-layer theory revisited. Water Resources Research, 45, W00C12.

Tang A.-M. \& Cui Y.-J. (2005) Controlling suction by the vapour equilibrium technique at different temperatures and its application in determining the water retention properties of MX80 clay. Canadian Geotechnical Journal, 42, 287-296.

Tripathy S., Thomas H.R. \& Bag R. (2017) Geoenvironmental application of bentonites in underground disposal of nuclear waste: characterization and laboratory tests. Journal of Hazardous, Toxic, and Radioactive Waste, 21, D4015002.

Villar M.V., Gómez-Espina R. \& Lloret A. (2010) Experimental investigation into temperature effect on hydromechanical behaviours of bentonite. Journal of Rock Mechanics and Geotechnical Engineering, 2, 71-78.

Villar M.V., Martín P.L., Romero F.J., Iglesias R.J. \& Gutiérrez-Rodrigo V. (2016) Saturation of barrier materials under thermal gradient. Geomechanics for Energy and the Environment, 8, 38-51.

Wang Q., Minh Tang A., Cui Y.-J., Delage P., Barnichon J.-D. \& Ye W.-M. (2013) The effects of technological voids on the hydro-mechanical behaviour of compacted bentonite-sand mixture. Soils and Foundations, 53, 232-245.

Xie M.L., Miehe R., Kasbohm J., Herb H.J., Meyer L. \& Ziesche U. (2012) Bentonite as barrier material for the sealing of underground disposal sites. Pp. 19-20 in: Bentonite Barriers - New Experiments and State of the Art. Gesellschaft für Anlagen- und Reaktorsicherheit (GRS), Cologne, Germany.

Ye W.M., Cui Y.J., Qian L.X. \& Chen B. (2009) An experimental study of the water transfer through confined compacted GMZ bentonite. Engineering Geology, 108, 169-176.

Ye W.M., Wan M., Chen B., Chen Y.G., Cui Y.J. \& Wang J. (2013) Temperature effects on the swelling pressure and saturated hydraulic conductivity of the compacted GMZ01 bentonite. Environmental Earth Sciences, 68, 281-288.

Yigzaw Z.G., Cuisinier O., Massat L. \& Masrouri F. (2016) Role of different suction components on swelling behavior of compacted bentonites. Applied Clay Science, 120, 81-90.

Yong R.N. \& Warkentin B.P. (1975) Soil Properties and Behaviour: Developments in Geotechnical Engineering. Elsevier, Amsterdam, The Netherlands. 